\title{
PEMBALIKAN BEBAN PEMBUKTIAN DALAM TINDAK PIDANA KORUPSI DI INDONESIA
}

\section{REVERSAL BURDEN OF EVIDANCE ON A CRIMINAL CORRUPTION IN INDONESIA}

\author{
Hasnawati, Saleh Muliadi, Hamdan Rampadio \\ Universitas Tadulako \\ Hasnasaharuddin0821@yahoo.co.id
}

\begin{abstract}
The research aim are to know the implementation of strict evidence in corruption committed in Indonesia and the constraint or obstacle faced by the corruption agency. The method of this research was normative juridical, because the research about reversal burden of proof of corruption in crime in Indonesia, which data obtained from primary, secondary, and tertiary legal materials. Research result reveal that implementation of proof in corruption cases is often felt to be ineffective and very burdensome to the Investigator apparatus therefor two theories of proof, namely the free theory embraced by the dependent and negative theory according to the law adopted by the public prosecutor or ordinary commonly called the theory reversal burden of limited proof and in balance, the dependent has the right to proved that he has not commited a criminal act of corruption and that the prosecutor still has the duty to verify the indictment. The obstacles faced by law enforcement in implementing the burdening system of proof on the handling of corruption crime, namely the Contraints for the public Prosecutor and the obstacle for the judge divided into 2(two) types, namely: Juridical and Non Juridical Contrains.

Key words : reversal system, burden of proof, corruption crime
\end{abstract}

\begin{abstract}
ABSTRAKSI:Tujuan penelitian ini untuk mengetahui penerapan pembalikan beban pembuktian dalam tindak pidana korupsi di indonesia dan hambatan atau menggambarkan kendala yang dihadapi oleh penegak hukum dalam penerapan sistem pembalikan beban pembuktian pada penanganan tindak pidana korupsi. Metode penelitian yang digunakan adalah penelitian yuridis normatif, yang menggunakan data-data yang diperoleh dari bahan-bahan hukum primer, sekunder, dan tersier. Hasil penelitian menunjukkan dua teori pembuktian, yaitu teori bebas yang dianut oleh terdakwa dan teori negatif menurut undang-undang yang dianut oleh penuntut umum atau biasa atau biasa disebut dengan teori pembalikan beban pembuktian terbatas dan berimbang, yakni terdakwa mempunyai hak untuk membuktikan bahwa ia tidak melakukan tindak pidana korupsi dan penuntut umum tetap berkewajiban membuktikan dakwaannya. Hambatan atau kendala yang dihadapi oleh penegak hukum dalam penerapan sistem pembalikan beban pembuktian pada penanganan tindak pidana korupsi, yaitu kendala bagi jaksa penuntut umum dan kendala bagi hakim dimana dibedakan menjadi 2 (dua) jenis, yaitu: kendala yuridis dan non yuridis

Kata kunci: sistem pembalikan, beban pembuktian, tindak pidana korupsi
\end{abstract}




\section{PENDAHULUAN}

Pembangunan nasional berdasarkan Pancasila dan undang-undang Dasar 1945 bertujuan untuk mewujudkan masyarakat Indonesia yang adil, makmur, dan sejahtera. Untuk itu, perlu secara terus-menerus ditingkatkan usaha pencegahan dan pemberantasan tindak pidana korupsi ${ }^{1}$ yang makin meluas dan meningkat dalam kuantitas dan kualitas. Hal tersebut dapat dilihat dari pola tindak pidana korupsi yang semakin sistematis serta makin merasuki berbagai aspek kehidupan masyarakat diberbagai lapisan.

Kondisi ini, tidak hanya merugikan keuangan Negara, tetapi juga merupakan pelanggaran terhadap hak sosial dan ekonomi masyarakat, sehingga tindak pidana korupsi perlu digolongkan sebagai kejahatan yang bersifat luar biasa. $^{2}$

Bila korupsi dijadikan extra ordinary crime ( kejahatan luar biasa ), implikasinya menjadi pemberantasan dan cara luar biasa dalam menangani korupsi. Kemungkinan timbul kondisi yang berlebihan yang bisa mengganggu kehidupan berbangsa dan bernegara, bila penegakkan hukum ditingkatkan menjadi luar biasa maka harus dicari rekrutmen penegak hukum yang bermoral serta sistem yang tepat dalam pembarantasan korupsi ${ }^{3}$.

Usaha untuk menanggulangi terjadinya kebocoran keuangan dan perekonomian negara (korupsi) sebenarnya sudah dimulai sejak dikeluarkannya beberapa Keputusan presiden seperti keputusan presiden Nomor 40 Tahun 1957 tentang keadaan perang hingga pada diberlakukannya Undang-Undang Nomor 24/Prp/1960 tentang Pengusutan, Penuntutan, dan Pemeriksaan Tindak Pidana Korupsi, akan tetapi meskipun undang-undang tersebut diberlakukan namun tidak mampu memberantas tindak pidana korupsi secara optimal. Alasan atas hal tersebut antara lain, karena undangundang tersebut tidak sesuai lagi dengan keadaan yang ada di lapangan, maka diganti dengan Undang-Undang Nomor 3 Tahun 1971 tentang Pemberantasan Tindak Pidana korupsi, tetapi ternyata kemudian undangundang inipun dipandang tidak berdaya pula memberantas tindak pidana korupsi maka undang-undang ini diganti dengan Undang-Undang Nomor 31 Tahun 1999 tentang Pemberantasan Tindak Pidana Korupsi, kemudian diadakan perubahan dan

\footnotetext{
${ }^{1}$ Penjelasan umum dalam Undang-Undang RI No. 31 Tahun 1999 tentang Pemberantasan Tindak Pidana Korupsi.

${ }^{2}$ Penjelasan Umum dalam Undang-Undang RI No. 31 tahun 2002 tentang Komisi pemberantasan Korupsi.
}

\footnotetext{
${ }^{3}$ Mansyur Semma, negara dan korupsi, pemikiran mochtar lubis atas negara, manusia Indonesia, dan perilaku politik, (Jakarta :yayasan obor Indonesia, 2008). h. 103.
} 
penyempurnaan berdasarkan Undang- bukanlah budaya negara kita. Karena Undang Nomor 20 Tahun 2001. budaya adalah sebuah nilai etis untuk

Penegakan hukum dan sistem membangun kehidupan manusia yang lebih hukum merupakan suatu hal yang baik. Sedangkan Korupsi pada dasarnya memainkan peranan penting dalam sebuah tindakan kriminal baik terhadap menciptakan masyarakat yang adil dan hukum maupun terhadap nilai yang ada makmur dalam rangka memajukan dalam masyarakat. Secara filosofis, korupsi perekonomian dan pembangunan nasional di satu pihak bukanlah sebuah kebudayaan bangsa. Salah satu yang menjadi penghambat dalam kemajuan sebab korupsi sungguh bertentangan dengan nilai dan unsur kebudayaan itu perekonomian dan pembangunan bangsa adalah korupsi.

Akibat yang ditimbulkan dari tindak pidana korupsi yang terjadi selama ini selain merugikan keuangan negara atau perekonomian negara, juga menghambat pertumbuhan dan kelangsungan pembangunan nasional yang menuntut efisiensi tinggi. Di tengah upaya pembangunan nasional di berbagai bidang, aspirasi masyarakat untuk memberantas korupsi dan bentuk penyimpangan lainnya semakin meningkat, karena dalam kenyataannya adanya perbuatan korupsi telah menimbulkan kerugian negara yang sangat besar. $^{4}$

Korupsi dinegeri ini sudah demikian parah, mengakar, bahkan sebahagian kalangan sudah menganggap bahwa korupsi telah membudaya. Akan tetapi korupsi

\footnotetext{
4 Penjelasan umum Undang-Undang Nomor 31 tahun 1999 tentang PemberantasanTindak Pidana Korupsi
} sendiri. Dengan demikian tindakan korupsi dan kebudayaan adalah dua hal yang sangat bertolak belakang. ${ }^{5}$ Dalam kasus perkara Tindak pidana korupsi tersebut tidak mengalami penurunan tapi malah cenderung meningkat dari tahun ke tahun, meskipin berbagai upaya telah dilakukan untuk mengatasi dan memberantasnya. ${ }^{6}$

Berkaitan dengan praduga tak bersalah sebagaimana yang disebutkan di atas, Undang-Undang No.48 Tahun 2009 tentang Kekuasaan Kehakiman dalam Pasal 8 telah mengatur lebih lanjut asas tersebut dengan menyatakan : Setiap orang, yang disangka, ditangkap, ditahan, dituntut atau dihadapkan di depan pengadilan, wajib dianggap tidak bersalah sebelum putusan pengadilan, yang menyatakan kesalahan dan memperoleh kekuatan hukum yang tetap. Sejalan dengan hal itu, Pasal 66

${ }^{5}$ Mochtar Pabottingi dari buku Saldi Isra, Kekuasaan dan Perilaku Korupsi, Kompas, Jakarta, 2009. h. VIII.

6 Mansyur Kataryasa, Korupsi dan pembuktian Terbalik, cibubur: 2017. h. 6. 
KUHAP mengatur “ Tersangka atau terdakwa tidak dibebani kewajiban beban pembuktian."

Untuk menindak kejahatan yang luar biasa ini, maka sangat dimungkinkan penindakan yang luar biasa pula, agar para penegak hukum tidak lagi segan-segan untuk melakukan beban pembuktian tersebut.

\section{METODE PENELITIAN}

Penelitian ini menggunakan metodologi penelitian yuridis normatif, yakni penelitian hukum yang berbasis atau mengacu kepada kaidah-kaidah atau norma- norma hukum yang terdapat dalam peraturan peraturan perundangundangan. Metode pendekatan yang digunakan dalam penelitian ini adalah pendekatan peraturan perundangundangan (statute approach). ${ }^{7}$ Pendekatan peraturan perundangundangan dilakukan dengan menelaah semua undang-undang dan regulasi yang bersangkut paut dengan isu hukum yang sedang ditangani. Pendekatan tersebut terkait dengan peraturan hukum yang mengatur tentang sistem pembalikan beban pembuktian serta menelaah bukubuku dan pendapat- pendapat ahli tentang sistem pembalikan beban pembuktian.

\footnotetext{
7 Peter Mahmud Marzuki, Penelitian Hukum, (Jakarta: Kencana Prenada Media Group, 2007), hlm. 93-95.
}

Jenis Dan Sumber Data

Data-data yang diperoleh dari bahanbahan hukum primer, sekunder dan tersier.

\section{Bahan Hukum}

Bahan Hukum yang digunakan dalam penulisan ini adalah bahan Hukum primer, sekunder dan tersier yang berkaitan dengan judul proposal ini Bahan hukum primer, berupa bahanbahan yang memiliki kekuatan mengikat, seperti norma dasar, peraturan peraturan perundang-undangan, khususnya Kitab Undang-undang Hukum Pidana (KUHP), Kitab Undang- undang Hukum Acara Pidana (KUHAP), Undang-undang Nomor 31 tahun 1999 tentang Tindak Pidana Korupsi, Undang-undang Nomor 20 tahun 2001 tentang Perubahan atas UU Nomor 31 Tahun 1999 tentang Pemberantasan Tindak Pidana Korupsi.

Bahan hukum sekunder, yang menjelaskan bahan hukum primer dan isinya tidak mengikat, seperti literatur tentang hukum pembuktian, hasil-hasil penelitian sarjana hukum, makalahmakalah dalam seminar tentang tindak pidana korupsi, artikel-artikel yang berkaitan dengan pengaturan dan implementasi sistem pembalikan beban pembuktian terhadap tindak pidana korupsi.

Bahan hukum tersier, yang sifatnya 
melengkapi bahan hukum primer dan sekunder, seperti Kamus Bahasa Indonesia, Kamus Hukum, aneka istilah hukum, ensiklopedia yang berkaitan dengan sistem pembalikan beban pembuktian terhadap tindak pidana korupsi.

\section{Metode Pengumpulan Data}

Data kepustakaan yang merupakan data utama penelitian dikumpulkan yang kemudian dilakukan analisis per masalahannya. Adapun bahan-bahan yang akan dikumpulkan antara lain permasalahan, asas-asas, argumentasi, implementasi yang ditempuh, alternatif pemecahannya yang berkaitan dengan pembalikan beban pembuktian.

Kemudian mengenai data kepustaka an yang digunakan adalah kepustakaan di bidang hukum pidana, khususnya hukum pidana khusus, hukum pembuktian dan aturan hukum lainnya yang berkaitan dengan sistem pembalikan beban pembuktian.

\section{Metode Analisis Data}

Metode pengolahan dan analisis data dalam penelitian ini bersifat kualitatif deskriptif dengan menguraikan persoalan dan fakta-fakta yang diuraikan secara tertulis dari bahan kepustakaan dan akan dianalisa dengan menggunakan pendekatan peraturan perundangundangan yang pada akhirnya akan ditarik sebuah kesimpulan.

Deskripsi dilakukan terhadap isi maupun struktur hukum yang berkaitan dengan sistem pembalikan beban pembuktian dalam hukum positif di Indonesia. yang bertujuan untuk dapat memberikan solusi atas permasalahan.

\section{HASIL DAN PEMBAHASAN}

\section{Penerapan pembalikan beban pembuktian dalam tindak pidana korupsi di Indonesia}

Tindak pidana korupsi adalah sebagaimana juga tindak pidana pada umumnya dilakukan dengan berbagai modus operandi penyimpangan keuangan Negara, yang semakin canggih dan rumit. Sehingga banyak perkara-perkara tindak pidana korupsi lolos dari "jaringan" pembuktian sistem KUHAP. Karena itu pembalikan beban pembuktian sebagaimana diterapkan dalam sistem beracara pidana di Indonesia.

Dalam penjelasan UU No. 31 Tahun 1999, dikatakan "pembalikan beban pembuktian yang bersifat berimbang", yakni terdakwa mempunyai hak untuk membuktikan bahwa ia tidak melakukan tindak pidana korupsi dan wajib memberikan keterangan tentang seluruh harta bendanya, dan harta benda istri atau suaminya, anak dan harta benda setiap orang atau koorporasi yang diduga mempunyai hubungan dengan perkara yang 
Universitas Tadulako.......................................(73-75)

bersangkutan dan Penuntut Umum tetap berkewajiban untuk membuktikan dakwaannya.

Kata-kata "bersifat terbatas" dalam memori pasal 37 dikatakan bahwa apabila terdakwa dapat membuktikan dalilnya "terdakwa tidak dapat melakukan tindak pidana korupsi”. Hal tersebut tidak berarti tidak terbukti melakukan korupsi, sebab Penuntut Umum masih tetap berkewajiban untuk membuktikan dakwaannya.

Kata-kata "berimbang" mungkin lebih tepat "sebanding" dilukiskan sebagai penghasilan terdakwa ataupun sumber penambahan harta benda, sebagai output tersebut ( misalnya berwujud mobil, saham, rumah-rumah, simpanan dollar dalam rekening bank, dan lain-lain) adalah hasil perolehan dari tindak pidana korupsi yang didakwakan.

Dalam pemeriksaan tindak pidana korupsi ada dua Hukum Acara Pidana yaitu Hukum Acara Pidana yang tercermin dalam UU No. 31 Tahun 1999 sebagai penyimpangan dari Hukum Acara pada KUHAP dan Hukum Acara pidana yang termuat dalam Kitab Undang-Undang Hukum Acara Pidana. Dalam pembuktian tindak pidana korupsi dianut dua teori pembuktian, yaitu :

Teori bebas yang dianut oleh terdakwa. Teori Negatif menurut Undang-Undang yang dianut oleh Penuntut Umum.
Teori bebas sebagaimana tercermin dan tersirat dalam penjelasan umum, serta berwujud dalam hal-hal sebagaimana tercantum dalam pasal 37 UU No. 31 Tahun 1999 sebagai berikut :

1. Terdakwa mempunyai hak untuk membuktikan bahwa ia tidak melakukan tindak pidana korupsi

2. Dalam hal terdakwa dapat membukti kan bahwa ia tidak melakukan tindak pidana korupsi, maka keterangan tersebut dapat digunakan sebagai hal yang tidak menguntungkan dirinya

3. Terdakwa wajib memberikan keterangan tentang seluruh harta bendanya dan seluruh harta benda isteri atau suami, anak, dan setiap badan atau koorporasi yang diduga mempunyai hubungan dengan perkara yang bersangkutan

4. Dalam hal terdakwa tidak dapat membuktikan tentang kekayaan yang tidak seimbang dengan penghasilan atau sumber penambahan kekayaannya, maka keterangan tersebut dapat dipergunakan untuk memperkuat alat bukti yang ada bahwa terdakwa telah melakukan tindak pidana korupsi.

5. Dalam keadaan sebagaimana dimaksud dalam ayat (1), (2), dan ayat (3) dan (4), Penuntut Umum tetap berkewajiban untuk membuktikan dakwaannya.

Sedangkan teori negatif menurut undang-undang tercermin tersirat dalam 
pasal 183 KUHAP yang berbunyi sebagai berikut :

" Hakim tidak boleh menjatuhkan pidana kepada seorang kecuali apabila dengan sekurang-kurangnya mempunyai dua alat bukti yang sah, ia memperoleh keyakinan bahwa suatu tindak pidana benar-benar terjadi dan bahwa terdakwalah yang bersalah melakukannya".

Karena itu persyaratan pemberian

pidana dalam sistem KUHAP sangat berat, yaitu:

1. Minimum dua alat bukti yang sah menurut undang-undang

2. Keyakinan hakim

3. Ada tindak pidana yang benar-benar terjadi

4. Terdakwa itu manusia yang melakukan perbuatan

5. Adanya kesalahan pada terdakwa

6. Macam pidana apa yang dijatuhkan hakim

Menurut Wirjono Prodjodikoro, bahwa teori pembuktian negatif menurut undang-undang sebaiknya dipertahankan berdasarkan dua alasan:

1. Memang sudah selayaknya harus adanya keyakinan hakim tentang kesalahan terdakwa untuk dapat menjatuhkan suatu pidana, jangan hakim terpaksa memberi pidana kepada seorang terdakwa sedangkan hakim tidak yakin akan kesalahan terdakwa

2. Bermanfaat jika ada aturan yang mengikat hakim, dan menyusun keyakinannya, agar ada patokan-patokan tertentu yang harus diturut oleh hakim dalam melakukan Peradilan ${ }^{8}$.

Sedangkan D. Simons menyatakan

bahwa teori pembuktian negative menurut

\footnotetext{
${ }^{8}$ WirjonoProdjodikoro, Hukum Acara Pidana Di Indonesia, Sumur Bandung 1997, hal. 74
}

undang-undang ini, pemindaan didasarkan pada pembuktian yang berganda yaitu pada peraturan undang-undang dan keyakinan hakim, dan menurut undang-undang. Dasar keyakinan hakim itu bersumber pada peraturan perundang-undangan ${ }^{9}$.

Bagaimana pada praktek peradilan di Indonesia ? Wiryono Paradjodikoro, pada kesempatan tukar pikiran antara hakim yang bercerita tentang pengalamannya sebagai Hakim/ketua sidang. Sering kejadian hakim mulai dengan menentukan keyakinannya dengan tentang terbukti atau tidaknya suatu kejadian dan kalau hakim yakin betul, bahwa terdakwa bersalah maka diusahakan supaya ada alat-alat bukti yang mencukupi syarat-syarat yang ditentukan oleh undang-undang agar dapat menjadi dasar keyakinan itu.

Selama belum ditetapkan adanya adopsi delik baru berupa berkaitan antara delik "gratification" (pemberian) dengan "Bribery"(penyuapan) berikut soal perampasan, maka implementasi sistem pembalikan beban pembuktian hanyalah sebuah retorika polisi saja.

Pembalikan beban pembuktian terhadap delik atau semua rumusan tindak pidana korupsi sungguh tidak dapat diterima, karena sangat jelas sistem ini akan melakukan pelanggaran terhadap prinsip perlindungan dan penghargaan terhadap

\footnotetext{
${ }^{9}$ D. Simons : 1952 , hal. 152
} 
Hak Asasi Manusia, khususnya perlindungan terhadap hak-hak prinsipiil terdakwa. Bahwa sebagai suatu ketentuan khusus, sudah cukuplah menjadi minimalisasi hak-hak terdakwa dan bukan serta tidak diharapkan adanya eliminasi hak tersebut. Minimalisasi penghargaan hakhak tersebut atas diberlakukannya delik baru tentang pemberian yang berkaitan dengan perbuatan "suap", bukan terhadap semua delik-delik yang ada dalam rumusan ketentuan Undang-Undang pemberantasan Tindak Pidana Korupsi tersebut.

Kehendak adanya keberlakuan Prinsip atau Asas Pembalikan Beban Pembuktian ini dilakukan terhadap penambahan undang-undang No. 31 tahun 1999.

Hambatan atau kendala yang dihadapi oleh penegak hukum dalam penerapan sistem pembalikan beban pembuktian pada penanganan tindak pidana korupsi

Kendala bagi Jaksa Penuntut Umum dibedakan menjadi 2 (dua) yaitu: Kendala yuridis yang meliputi:

(a) Kesulitan pembuktian di persidangan, dikarenakan para saksi a charge yang diajukan di persidangan mencabut kembali pernyataan yang telah diberikan sebagaimana dalam Berita Acara Pemeriksaan (BAP) di tingkat penyidikan. Selain itu, para saksi pada umumnya mempunyai hubungan kerja dengan terdakwa, yaitu terdakwa sebagai atasannya sehingga keterangan yang diberikan cenderung memberi pembelaan (meringankan) terdakwa; (b) Pengembalian kerugian negara sebagai unsur dalam tindak pidana korupsi telah dikembalikan oleh terdakwa sehingga terdakwa tidak dapat dituntut melakukan tindak pidana merugikan keuangan negara. Akibat hukumnya bahwa terdakwa tidak dapat dijerat/terlepas dari Undang-Undang Pemberantasan Tindak Pidana Korupsi. Tetapi pada dasarnya, delik korupsi merupakan delik formil sehingga titik berat celaan ada pada perbuatannya. Ketentuan delik korupsi sebagai delik formil ditegaskan dalam Pasal 4 UU No. 31 Tahun 1999 sebagaimana telah diubah dengan UU No. 20 Tahun 2001 yang menyatakan bahwa pengembalian kerugian keuangan negara atau perekonomian negara tidak menghapuskan dipidananya pelaku tindak pidana;

(c) Pengungkapan terjadinya tindak pidana korupsi dengan sistem pembalikan beban pembuktian memakan waktu persidangan yang lama sehingga membuat kesulitan untuk mendapatkan dan mengumpulkan bukti-bukti yang ada. Kasus adanya dugaan korupsi tersebut baru terungkap setelah terdakwa menjalani masa pensiun, sedangkan terjadinya korupsi tersebut sewaktu terdakwa masih aktif bekerja dan memegang jabatan tertentu;

(d) Berlakunya asas oportunitas yaitu penyampingan perkara pidana demi kepentingan umum. Apabila suatu perkara yang diperiksa oleh penyidik dinilai merugikan kepentingan umum, maka proses perkara tersebut dapat diberhentikan. Semisal dikeluarkanya Surat Perintah Penghentian Penyidikan oleh Kejaksaan Agung sehingga penuntutan perkara korupsi tersebut tidak dapat diteruskan.

Kendala non yuridis yang meliputi:

(a) Kendala teknis operasional seperti minimnya sarana-prasarana atau peralatan dan minimnya anggaran dana operasional tetapi Kejaksaan tetap 
berupaya untuk mengungkap dan menangani kasus korupsi;

(b) Kekurangan jumlah tenaga Jaksa tindak pidana khusus yang profesional dalam menangani kasus korupsi sehingga peraturan perundang-undangan yang ada belum diterapkan secara maksimal.

Kendala bagi Hakim dibedakan menjadi 2 (dua) yaitu:

Kendala yuridis yang meliputi:

(a) Saksi memberikan keterangan yang memperkuat dakwaan Jaksa dalam proses persidangan tetapi ketika pembuktian tiba-tiba saksi mencabut keterangan yang pernah diberikan sebelumnya;

(b) Tindak pidana korupsi sulit pembuktiannya karena Jaksa ragu dalam membuktikan. Maka Hakim melihat dua sisi baik pembuktian oleh terdakwa maupun pembuktian oleh Jaksa, untuk mengambil kesimpulan;

(c) Sistem pembuktian terbalik sulit diterapkan karena ada kemungkinan Hakim bisa memberi putusan onslag van alle rechtsvervolging atau bebas (vrispracht), apabila terdakwa dapat membuktikan dia tidak bersalah.

Kendala non yuridis yang meliputi:

(a) Berkas perkara korupsi dipaksa dilimpahkan ke pengadilan sebagai hasil penyidikan yang dipaksakan oleh Jaksa yang mengakibatkan sulitnya proses pembuktian di persidangan. Dalam hal ini keterangan para saksi yang diajukan di pengadilan tidak ada sinkronisasi;

(b) Apabila panitera pengganti tidak mampu mencatat dengan cermat dan cepat atas keterangan terdakwa yang disampaikan dengan cepat maka bisa dimungkinkan hasil pencatatan atas keterangan terdakwa tidak sesuai dengan harapan Hakim.

Dengan demikian, dari kendala yuridis dan kendala non yuridis yang dihadapi oleh Jaksa dan Hakim tersebut diatas terlihat bahwa penerapan sistem pembuktian terbalik sebenarnya tidak didukung oleh peran/sikap Jaksa dan Hakim sebagai aparat penegak hukum. Namun apabila diterapkan sistem pembuktian terbalik pada proses persidangan tindak pidana korupsi sebenarnya memiliki kekuatan, yaitu efektif bagi terdakwa yang betul-betul dapat membuktikan secara optimal bahwa harta kekayaannya bukan dari hasil tindak pidana korupsi. Sebaliknya kelemahan sistem pembuktian terbalik dianggap tidak efektif bagi Jaksa Penuntut Umum sebab membuat lama proses persidangan. Sedangkan kelemahan sistem pembuktian terbalik bagi terdakwa, apabila hak membuktikan secara terbalik tidak diterapkan secara optimal, maka akan memperkuat alat bukti yang diajukan oleh Jaksa Penuntut Umum bahwa terdakwa terbukti melakukan tindak pidana korupsi. Pengungkapan tindak pidana korupsi khususnya pada saat pembuktian sebenar nya tidak mengalami kesulitan apabila dilakukan tindakan secara terintegrasi dari lembaga penegak hukum baik Kejaksaan dan Pengadilan melalui integrated criminal justice system, artinya diantara lembaga penegak hukum harus memiliki suatu balanced and equal of power, suatu kewenangan yang berimbang dan sama 
Universitas Tadulako........................................ 73 - 75)

diantara para penegak hukum untuk penerapan sistem pembalikan beban mencapai putusan yang adil. pembuktian pada penanganan tindak

\section{PENUTUP}

\section{Kesimpulan}

Pembalikan beban pembuktian dalam tindak pidana korupsi diterapkan dua jenis sistem pembalikan beban pembuktian sebagaimana diatur dalam UU No. 31 tahun 1999 dan KUHAP. Kedua teori ini menerapkan Hukum pembuktian dilakukan dengan cara menerapkan pembalikan beban pembuktian yang bersifat terbatas dan berimbang dan menggunakan sistem pembuktian negatif menurut Undangundang (negative wettelijk overtuinging). Tidak menerapkan teori pembalikan beban pembuktian murni (zivere oms keering bewijstlast), tetapi teori pembalikan beban pembuktian terbatas dan berimbang. Pembalikan beban pembuktian yang bersifat terbatas dan berimbang yakni mempunyai hak untuk membuktikan bahwa ia tidak melakukan tindak pidana korupsi dan wajib memberikan keterangan mengenai seluruh harta benda setiap orang atau koorporasi yang diduga mempunyai hubungan dengan perkara yang bersangkutan dengan Penuntut Umum tetap berkewajiban untuk membuktikan dakwaannya.

Hambatan atau kendala yang dihadapi oleh penegak hukum dalam Penuntut Umum dan kendala bagi Hakim dimana dibedakan menjadi 2 (dua) jenis, yaitu: Kendala Yuridis dan Non Yuridis.

\section{Saran}

Agar kiranya Hakim dalam menentu kan terdakwa bersalah berdasarkan pembalikan beban pembuktian diusahakan supaya ada alat-alat bukti yang mencukupi syarat-syarat yang ditentukan oleh Undangundang agar dapat menjadi dasar keyakinan Hakim di dalam menjatuhkan putusan sehingga implementasi sistem pembuktian tidak hanya retorika politis saja.

Peraturan perundang-undangan sudah baik maka penerapannya harus ditingkatkan dan diefektifkan penggunaannya khususnya pembalikan beban pembuktian ini dalam menangani perkara-perkara korupsi.

Penegakan hukum dalam memberan tas tindak pidana korupsi, perlu diperhatikan keseimbangan antara faktorfaktor yang dapat mempengaruhi proses penegakan hukum, yaitu faktor peraturan perundang-undangan, dalam arti UU No. 31 Tahun 1999 sebagaimana telah diubah dengan UU No. 20 Tahun 2001. 
Kewenangan hakim untuk melaksana khususnya Jaksa dan Hakim dengan kan sistem pembuktian terbalik dalam kewenangannya seharusnya memiliki proses persidangan tindak pidana korupsi, kemauan yang kuat untuk melaksanakan factor moralitas dan profesionalis me dari sistem pembuktian terbalik, tanpa harus aparat penegak hukum yang terlibat dalam menunggu pengajuan terdakwa untuk proses persidangan tindak pidana korupsi, melaksanakan hak atas pembuktian terbali

\section{DAFTAR PUSTAKA}

Mansyur Semma, 2008. Negara dan Korupsi, Pemikiran Mochtar Lubis Atas Negara, Manusia Indonesia, Dan Perilaku Politik, :Yayasan Obor Indonesia, Jakarta.

Mochtar Pabottingi, 2009. Kekuasaan dan Perilaku Korupsi, Kompas, Jakarta.

Peter Mahmud Marzuki, 2007. Penelitian Hukum, Kencana Prenada Media Group, Jakarta.

Wirjono Prodjodikoro, 1997. Hukum Acara Pidana Di Indonesia, Sumur Bandung Firman Wijaya, 2008. Peradilan Korupsi Teori dan Praktik, penaku bekerjasama dengan Maharini Press, Jakarta.

Lilik Mulyadi, Pembalikan Beban Pembuktian,

Indriyanti Seno Adji, 2006. Korupsi dan Pembalikan Beban Pembuktian, Kantor Pengacara dan Konsultan Hukum Oemar Seno Adji, Jakarta.

Indriyanto Seno Adji, 2009. Korupsi dan Penegakan Hukum, Diadit Media, Jakarta. Undang- Undang RI No. 31 Tahun 1999 tentang Pemberantasan Tindak Pidana Korupsi. 